To cite this document: Daniela Nascimento (2018) Peace Processes and the Role of Spoilers: A Critical Assessment, International Peacekeeping, 25:4, 591-593, DOI: $\underline{10.1080 / 13533312.2018 .1483194}$

To link to this document: https://doi.org/10.1080/13533312.2018.1483194

REVIEW ESSAY

\title{
Peace Processes and the Role of Spoilers: A Critical Assessment
}

Comparative peace processes, by Jonathan Tonge, Cambridge, Polity Press, 2014, 195 pp. + Bibliography + Index, $£ 17.99$ (pbk), ISBN: 9780745642901

Fighting over peace: spoilers, peace agreements and the strategic use of violence, by Andrew G. Reiter, London, Palgrave Macmillan, 2016, 162 pp. + Appendixes + Index, \$129.00 (hbk), ISBN: 9783319401010

The two books under review both start from the assumption that there has been a notable evolution the study of peace processes since the end of the Second World War, and both authors - Jonathan Tonge, and Andrew G. Reiter - clearly signal their intent to contribute to the further advancement of the theoretical debate on the role and impact of peace processes and peace agreements in addressing violent civil conflict. To do so, they also both engage in extensive case study analysis, but of different cases, thus adding an important empirical dimension to the debate.

Tonge's book is structured in two interrelated parts. The first section is more theoretical, focusing on the central concepts of peace, peace processes, and conflict management and resolution, combined with an analysis of key issues that directly or indirectly influence the success or failure of peace processes: implementation, of peace agreements, how to deal with past legacies of the violent conflict, among others. The second section is more empirical, and is based on the analysis of several case studies displaying various types of peace processes in varied contexts, thus illustrating different conflict dynamics as well as different outcomes and levels of success: Palestine, Lebanon, Sri Lanka, BosniaHerzegovina and the Basque Country (Euskadi Ta Askatasuna).

The overall goal of Tonge's book is to clarify both the central and peripheral elements of peace processes in order to assess the extent to which they contributed to the 
transformation of the conflict (4). He does so by resorting to a distinctive analytical approach that combines assessment of the growth of peace processes, of conflict management tools - namely restorative justice and reconciliation mechanisms - and of the potential of consociational power-sharing mechanisms to help achieve conflict management goals (1), particularly in conflict settings characterized by ethnic rivalries. Regarding the latter, Tonge does not deny a certain 'sympathy' towards consociational solutions in peace processes applied to divided societies - such as the ones put forward in Northern Ireland and Bosnia-Herzegovina - for the simple reason that by acknowledging division, these can offer a 'continuous management of conflict rather than relying upon a “one-off” big deal to settle issues' (193). However, the author stresses that these arrangements do not necessarily apply to every conflict nor to every divided society, and that each society's conditions and dynamics must be taken into account. Finally, it is worth noting the relatively optimistic argument defended by the author regarding these processes and strategies: he suggests that despite the complexity and permanent nature of these divisions, there is always a solution for violence and to a great extent, and it is up to the peace process put forward to create the necessary conditions to achieve that goal.

To a certain extent, this is a topic shared by Reiter's book in that he also focuses on what can be done to make peace processes endure and successfully end violent civil conflict. The nuance of Reiter's analysis lies in his emphasis on actors and factors - violence in particular - that can undermine and spoil peace processes and peace agreements, especially since he departs from the general consensus that violence directed at peace agreements poses a serious threat to the successful implementation and maintenance of peace.

Following Stephen Stedman's 'footsteps', Reiter seeks to give substance to the meaning of spoilers and spoiling as a particularly important challenge to peace in contemporary civil wars. He does this by trying to answer three central questions: first, who are spoilers and what type of actors - both internal and external - engage in spoiling behaviour? Second, where and why does spoiling occur? Third, what impact does spoiling have on peace efforts? The answers to these three questions are sought through a combination of qualitative and quantitative analysis based on a dataset that includes 300 civil war peace agreements signed since the beginning of the 1990s. Through this analysis, he aims to overcome the many obstacles and limitations experienced by both academics and policymakers in actually and accurately predicting spoiler emergence after peace 
agreements. Starting from an innovative analytical and theoretical framework that helps the reader understand the broader debate on the role of violence and spoilers in peace processes, he then moves to an empirical analysis of several case studies aimed at sustaining his argument and helping find the answers to his central questions.

His conclusions are clear. First, spoiling is fundamentally a bargaining tool that is employed when other strategies to undermine peace processes, by both insiders and outsiders, prove to be ineffective. These actors include, among others, state, military, paramilitary, and rebels and they have varying capacities and objectives. Importantly, this demonstrates that it is not only extremists who oppose peace that engage in spoiling. Second, through his extensive qualitative and quantitative analysis of various peace processes, Reiter argues that spoiling poses a significant threat to peace agreements only under specific circumstances and that in some cases, it can even reinforce peace in the longer term. These findings, of course, have important policy implications for those engaged in peace negotiations who want to avoid and/or prevent the threats posed by spoilers. This can be done by through a number of strategies and processes: predicting and preventing spoilers and spoiling; targeted inclusion of potential spoilers; continued negotiation; and coercion. Ultimately, Reiter's findings allow for a more accurate and more in-depth understanding of spoilers and spoiling, which will in turn lead to betterdesigned peace agreements and more effective peace processes.

While these two books are in some senses similar, and in others, including their specific aims, quite different, both contribute innovative insights that will be of value for academics, practitioners and policymakers working in this particular and very subjective field of research. Indeed, their shared broader objective, of advancing our understanding of conflict, peace processes, and their implementation in conflict-prone societies, is one that they both achieve - as well as one that should be continued.

Daniela Nascimento Universidade de Coimbra danielan@fe.uc.pt 